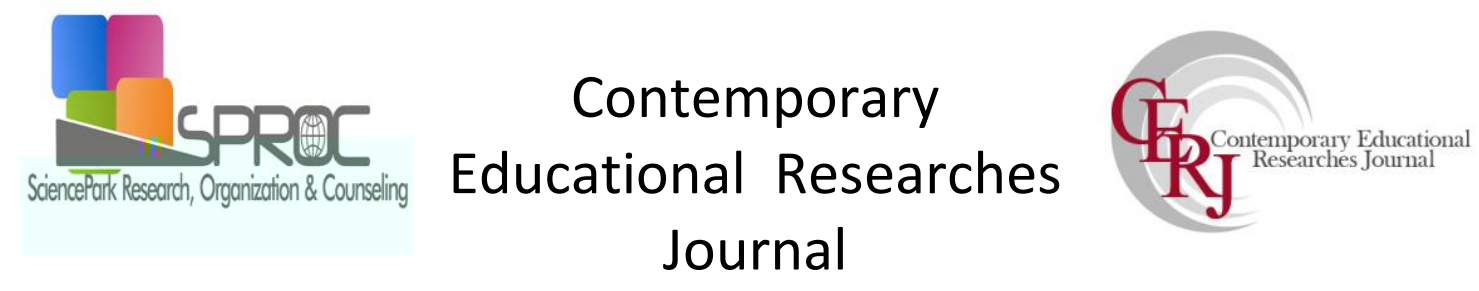

Volume 05, Issue 2, (2015) 70-76

http://sproc.org/ojs/index.php/ceri

\title{
The teaching of terminological literacy basics to engineering students
}

Elvira Yakovlevna Sokolova*, National Research Tomsk Polytechnic University, 30, Lenin Ave., Tomsk, 634050, Russia.

Suggested Citation:

Sokolova, E.Y. (2015). The teaching of terminological literacy basics to engineering students. . (2), 70-76.

Received 12 September, 2015; revised 30 October, 2015; accepted 24 November, 2015.

Selection and peer review under responsibility of.Prof. Dr. Gulsun Atanur Baskan, Hacettepe University, Turkey

${ }^{\circ} 2015$ SciencePark Research, Organization \& Counseling. All rights reserved.

\begin{abstract}
The article analyses the significance of the formation of students' terminological literacy in the process of English for Specific Purposes teaching at technical university and describes the conditions providing the efficiency of this process. The author emphasizes the necessity to a create terminological thesaurus which includes the most frequent systemized specialized discipline specific vocabulary and specialized subject area word families required to professional-oriented oral and written communication and provides logically-semantic orientation in the text. The author specifies the factors assumed as a basis for terminological corpus selection, shows the procedure of thesaurus creation and describes the activities used to teach terminological literacy.
\end{abstract}

Keywords: Terminological literacy, English for Specific Purposes, terminological thesaurus, specialized discipline specific vocabulary, professional-oriented oral and written communication.

*ADDRESS FOR CORRESPONDENCE: Elvira Yakovlevna Sokolova, National Research Tomsk Polytechnic University, 30, Lenin Ave., Tomsk, 634050, Russia. sokolovaeya@mail.ru 
Sokolova, E.Y. (2015). The teaching of terminological literacy basics to engineering students. (2), 70-76.

\section{Introduction}

In accordance to the basic regulating documents being in force in the Russian Federation concerning the English for Specific Purposes (ESP) teaching at technical universities (the Federal state educational standard, the educational standard of TPU, and the ESP course syllabus) the main emphasis in language training should be on the professional communication teaching by active implementation of information and communication technologies. The European standards and Guidelines for Accreditation of Engineering Programmes (ENAEE) also emphasize the importance of the development of global and critical thinking and communication skills in their oral and written form through the professional training of engineering students. Therefore, the acquisition of foreign communication skills in professional areas is the key aim of the special course "Professional English" taught to forth year students at Tomsk Polytechnic University. The professional English course (or ESP course) should be tailored to specific needs of trainees. Terminological literacy is an important and essential component of professional and language competence of future engineering specialists, since special lexis and terminology reflect the content of their future profession and they are also important tools for the formation of scientific conceptions, theories and laws. The correct context use of the terms is one of the key factors of the students' integration in the global academic society.

The aim of this article is to analyze the significance of students' terminological literacy formation through the ESP teaching. The author states that rational approach to the selection and organization of the instructional content and systematic methodical work at all stages of the educational process are required to ensure adequate comprehension of engineering textbooks and succeed in improvement of terminological competence, since the terminological literacy is the key component of future engineering specialist professional and language competences.

One of the components of teaching terminological literacy basics is the creation of terminological thesaurus which reflects the semantic links between different elements of the language. Terminological thesaurus includes the systemized specialized discipline specific lexical units required for adequate comprehension of engineering textbooks and professional-oriented oral and written communication. To acquire the terminological units presented in the terminological thesaurus a set of special tasks and exercises was developed. Some of these tasks and exercises are presented in the given article.

\section{Methodology}

Modern engineering term system is one of the most complicated and dynamic. It contains several thousands of words, word families, abbreviations, acronyms, and includes technical terms from all engineering fields and disciplines. There is a sustainable tendency of the growth of number of terminological units with rapid technological advances. The term as a language sign is subject to semantic and grammatical laws and has some special morphological characteristics inherent to the language signs and can undergo changes typical for lexical units of common lexis (Kobenko \& Zyablova, 2013). The basis of professional communication comprises specialized discipline specific lexis and terms since this vocabulary is tightly connected with the people's professional activity and provides practical realization of the content-related part of their professional communication. For compression of some complicated terminological compounds and collocations acronyms are used that function as integral units (Kobenko \& Zyablova, 2013). The term carries out several functions associated with cognitive and communicative activities. These functions include the knowledge acquisition, its interpretation and transfer (Grinev-Grinevich, 2008). In accordance with the existing theory the development of knowledge occurs when the old concepts and definitions expressed by a term are concretized, revised and rethought and some new concepts are introduced (Deniko \& Shitova, 2015).

The attempt to create a terminological thesaurus for students specializing in power and electrical engineering who learn ESP is determined by the effort to systemize and put in order terminological units to help students to avoid inaccurate use of specialized discipline specific 
Sokolova, E.Y. (2015). The teaching of terminological literacy basics to engineering students. . (2), 70-76.

lexis in the field of professional communication. By the selection of terminological units for the e-learning ESP course developed for fourth year students majoring in power and electrical engineering two leading approaches were used: the contextual and functionally content-related suggested by Kolesnikova and Dolgina (2001). These approaches allow, on the one hand, the relevant terminology selection and, on the other hand, they provide their definition, description and help to demonstrate the area of the terms and specialized discipline specific lexis use in the context.

\section{Results and discussion}

To find out fourth year students' needs concerning ESP course, the level of their terminology comprehension and competence an experimental research at the Institute of Power Engineering of National Research Tomsk Polytechnic University was conducted. This research was based on specially-developed tests on two modules "General Power Engineering" and "Electric Machines and Drives". By the selection of terminology and specialized discipline specific vocabulary for this research a special attention was paid to the terms and words, which are mostly frequently used in scientific and scientific and technical articles and texts containing information about power systems, energy equipment, power plants, substations, electric machines and drives. The materials for this research were prepared by the counseling assistance of specialists from technical departments. To conduct this research authentic engineering textbooks were downloaded from the e-book database and special authentic dictionaries and encyclopedias were used.

Analyzed and processed data of the conducted research showed that from the list of the terms and specialized discipline specific vocabulary about $55-65 \%$ of the total number of the words are unknown and unfamiliar to fourth year students (there were 7 groups consisting of 72 students). We came to the conclusion that it is impossible to improve and form terminological literacy in the ESP teaching-learning process without acquiring special terminology and specialized discipline specific lexis.

For the correct selection of the language material related to a certain subject area (in our case power and electrical engineering) it is necessary to specify factors that effecting methodological organization of this material:

- the selection of this material should be carried out in accordance with the regulating documents and ESP course syllabus taking into account power and electrical engineering students communicative needs;

- the selection of the language material should be carried out in accordance with the students language level, their basic knowledge and skills, their professional interests and individual and age peculiarities;

- representativeness considered as the ability of the selected material to present the terminological variety of the subject with maximum objectivity and authenticity;

- the consideration of frequency and concordance of specialized discipline specific lexis and its semantic significance which is considered as the ability to realize links between structural models, meaning content and situation;

- the consideration of the contextual use of words, their paradigmatic environment and stylistic features of scientific and technical texts since the Engineering English Word List should be learned in context rather than in isolation (Hsu, 2014);

- methodologically proved selection of the language material volume based on the principles of sufficiency which allows the students to carry out their oral and written professional-oriented communication;

- acquisition, accumulation and growth of terminological vocabulary is possible by the complex approach to the development of all kinds of speech activity. 
Sokolova, E.Y. (2015). The teaching of terminological literacy basics to engineering students. . (2), 70-76.

It is to be noted that the procedure of the terminological thesaurus creation and the activities used to acquire specialized discipline specific lexical units includes several stages:

- the determination of the principles used to select the lexical material;

- the determination of the methodically relevant volume of lexical material subject to active and passive acquisition;

- elicitation of features and regularities of classroom and self-study organization concerning lexical skills improvement;

- the development of methodical systems of classroom and self-study organization concerning lexical skills improvement;

- the approbation of the lexical material and its evaluation through its practical use in different learning activities.

Upon the analysis of the characteristics and features of the ESP language in its productive oral and written forms we came to the conclusion of the importance and necessity to teach and form the terminological literacy on the basis of text corpora presented in the information block of the e-learning ESP course presented in MOODLE. This information block includes:

- video lectures, video films, movie-reels;

- scientific, scientific and technical texts, scientific articles both in paper and electronic forms taken from encyclopedias, dictionaries, textbooks, students' books, study guides, and journals.

The choice of the information block consisting of specialized texts and video materials is methodically justified. Firstly, when working with the text the students can observe and understand the logic of the English language, they can acquire coherence and cohesion tools required to follow the idea development. They also can see how the terms work and how they are used in the context. Thus, the students are able to learn the terminology faster and consciously. Secondly, the information block is a methodical, conceptual and informative recourse for ESP teaching. Texts from the information block reflect some certain subject area and they are supplied with different visuals and graphical tools. Graphical tools (tables, piecharts, mind maps, bar-charts, diagrams, multimedia elements, and et al.) incorporated into the main body of the text help to present information in colorful non-linear manner, display, explore, compare or summarize numerical data, highlight patterns and trends, show the results of experiments, illustrate an argument or convey complex or detailed information in a concise manner. A critical issue when choosing a graphical tool is to ensure that the graph type selected is the most appropriate for the data and helps the students to interpret the information. The use of different types of visuals allows students to acquire bulk of theoretical material of high level of abstraction which is vital for ESP students. The study of ESP language based on visuals, images, pictures and graphical tools stimulates the activity of both hemispheres, cognitive activity, develops memory and critical thinking which is of great importance for students' active independent cognitive involvement at learning a foreign language (Zyubanov, 2012).

Specialized discipline specific lexis and terminology are presented in e-learning course developed for the fourth year students majoring in power and electrical engineering in the "Glossary" section. Glossary in the form of "conceptual terminological thesaurus" provided with "video glossary" includes the detailed interpretation of the English terms in the specified subject area, their correct pronunciation, examples of their use in the context with the application of multimedia technologies. If necessary, the definition of the term is supported by flash cards, movie-reels and video examples. Moreover, if a term appears anywhere in the text it can by means of hyperlinks be transformed into the reference where students can find its interpretation. E-learning course enables students to create and post their own thesaurus. Since the power and electrical engineering is based on the achievements of other fundamental sciences we suggest including interdisciplinary academic vocabulary and general scientific lexis in the terminological thesaurus created for students majoring in electrical and power engineering. 
Sokolova, E.Y. (2015). The teaching of terminological literacy basics to engineering students. . (2), 70-76.

The teaching of terminological literacy basics is carried out systematically by doing different home and classroom activities, tests and tasks. The teaching of terminological literacy basics includes three stages: preparatory stage with the semantization of terminological units and improvement of skills to work with a dictionary. The second stage is focused on the analysis of the text construction algorithm. Students are taught to get the required professionally significant information from the text, process it and then use it in accordance with the specified tasks. The third stage is concerned with the actualization of specialized discipline specific lexis in all types of speech activities. When students know the algorithm of text construction they are able to produce their own texts.

Tasks and exercises based on skimming and scanning reading strategies are often used to form and improve terminological literacy. The examples of these activities are as follows:

- read the text, create your own terminological glossary and compare your glossary with your peer-student;

- use the developed term list and give the main idea of this text;

- read the text and define the meaning of the underlined terms;

- fill in the gaps in the text using appropriate terms from the box;

- read the given scientific article, create your own terminological glossary and write an abstract to the article of $200-250$ words giving a brief account of the most relevant aspects of the paper.

For improvement of terminological literacy basics it is reasonable to use tasks and exercises that are focused on the matching of a certain lexical unit with other lexemes of the same semantic and thematic group. The process of terminological literacy improvement is also associated with the knowledge of word formation, the accurate choice and use of lexical unit in a certain context complying with logical, stylistic and grammatical structure. The main types of tasks used to practice the above mentioned skills are exercises which deal with logical and semantic grouping: mind maps, matching and puzzles. Systematic practice of those types of exercises results in acquisition, growth and activation of lexical-terminological units in interesting and cognitive forms. It is necessary to bear in mind the translation features inherent to terminological units. The translation of the term from one language into another one is justified when the meaning content of the terminological unit is not clear, but Kobenko (2011) thinks, that it is necessary to avoid translation when it hinders the objectivation of the true meaning content of this unit. 
Sokolova, E.Y. (2015). The teaching of terminological literacy basics to engineering students.

$$
\text { . (2), 70-76. }
$$

Thus, the top-priority task of the teaching of the language of professional communication in its oral and written forms is the improvement of lexical skills on the basis of planned structured and representative sample of terminological units particular to students' area of study and field.

\section{Conclusion}

Upon the analysis made we came to the conclusion that the main factors positively influencing the lexical skills improvement are: contextual semantization, problematic nature of communicative situation and maximal rotation of trained lexis.

The process of terminological literacy training and improvement can be successful when complying with the following conditions:

- the selection of the terminological units should be done in the cooperation with the specialists from technical departments and in accordance with the students' needs;

- the adjustment of the teaching material to the students' language level, their individual experience, affording them the opportunity to develop own learning trajectory;

- learning mode optimization due to rational combination of classroom activities and selfstudy;

- efficient use of information and communication technologies;

- systematic monitoring and objective control of the development of lexical skills, which discipline students and encourage them to regular self-study;

- interdisciplinary approach to the ESP teaching realized in the integration of the language and specialized subject area training;

- high terminological competence of lecturers and instructors;

- the acquisition of ESP language in the unity with students' professional competence development, their education and culture (Shcherbinina, 2007).

Therefore, to form the basics of terminological literacy we have put in order specialized discipline specific lexis by selection of the most relevant, stable and common terminological units and collocations with their corresponding synonyms and homonyms. Professional-oriented scientific and technical text corpus has been chosen as the basis for the selection of the terminological units and methodical organization of the teaching process. To form the basics of terminological literacy rational approach to the selection and organization of instructional content with systematic work at each stage of the teaching process is required. This process should be aimed at the development of practical skills concerning professional communication in its productive oral and written forms. Developed tasks train students to use terminology correctly, accurately and confidentially. The knowledge of the terminology will contribute to improvement of students' communicative and professional competences and allows them to meet the international standards concerning the analysis of information, conceptualization of concepts and solution of engineering problems.

\section{References}

Deniko, R.V., \&Schitova, O.G. (2015). Terminologija issledovanija v ramkah internacionalizacii vysshego obrazovanija. Moskva: 558 - 561. [Terminology studies in the frame of the internationalization of higher education.

Grinev-Grinevich, S.V. (2008).

Moskva: Akademiya. [ ]. (Rus.)

Hsu, W. (2014). Measuring the vocabulary load of engineering textbooks.

]. (Rus.) 54-55. 
Sokolova, E.Y. (2015). The teaching of terminological literacy basics to engineering students.

$$
\text { . (2), 70-76. }
$$

Kobenko, Yu.V. (2011). Lingvisticheskie osobennosti obucheniya yazyku professional'nogo obshcheniya.

[Linguistic features of professional communication teaching.

$$
\text { ]. (Rus.) }
$$

Kobenko, Yu.V., \& Zyablova, N.N. (2013). Strukturnye osobennosti terminologicheskikh akronimov v tekstakh angliiskogo nauchno-tekhnicheskogo stilya sfery vozobnovlyaemykh istochnikov energii (VIE).

71-73. [Structural features of terminological acronyms in the texts of English scientific and technical style of renewable energy sources sphere ]. (Rus.)

Kolesnikova, I.L., \& Dolgina, O.A. (2001).

Russian Baltic Information Center "BLITZ". [

St. Petersburg: Publishing House

Shcherbinina, L.D. (2007).

$$
\text { ]. (Rus.) }
$$

38-42. [

\section{]. (Rus.)}

Zyubanov, V.Yu. (2012). Sozdanie uslovii aktivnoi samostoyatel'noi poznavatel'noi deyatel'nosti pri izuchenii inostrannogo yazyka soobrazno psikhologicheskim osobennostyam budushchego spetsialista.

[Creation of active independent cognitive involvement at learning a foreign language in accordance with physiological features of the future specialist.

$$
\text { ]. (Rus.) }
$$

